\title{
NOP53 wt Allele
}

National Cancer Institute

\section{Source}

National Cancer Institute. NOP53 wt Allele. NCI Thesaurus. Code C54279.

Human NOP53 wild-type allele is located in the vicinity of $19 q 13.3$ and is approximately 12 $\mathrm{kb}$ in length. This allele, which encodes ribosome biogenesis protein NOP53, is involved in tumor suppression, the cellular response to stress and ribosome maturation. 